Contested Embrace 

Studies of the Walter H. Shorenstein Asia-Pacific Research Center

Andrew G. Walder, General Editor

The Walter H. Shorenstein Asia-Pacific Research Center in the Freeman Spogli Institute for International Studies at Stanford University sponsors interdisciplinary research on the politics, economies, and societies of contemporary Asia. This monograph series features academic and policy-oriented research by Stanford faculty and other scholars associated with the Center. 



\section{Contested Embrace}

TRANSBORDER MEMBERSHIP POLITICS IN

T W E N T I E T H - C E N T U R Y KO R E A

Jaeeun Kim

Stanford University Press

Stanford, California 
This work was supported by the Academy of Korean Studies (KSPS) Grant funded by the Korean Government (MOE) (AKS-20II-BAA-2IO2).

Stanford University Press

Stanford, California

(C) 2016 by the Board of Trustees of the Leland Stanford Junior University. All rights reserved.

No part of this book may be reproduced or transmitted in any form or by any means, electronic or mechanical, including photocopying and recording, or in any information storage or retrieval system without the prior written permission of Stanford University Press.

Printed in the United States of America on acid-free, archival-quality paper

Library of Congress Cataloging-in-Publication Data

Names: Kim, Jaeeun, author.

Title: Contested embrace : transborder membership politics in twentieth-century Korea / Jaeeun Kim.

Other titles: Studies of the Walter H. Shorenstein Asia-Pacific Research Center. Description: Stanford, California : Stanford University Press, 2016. | Series: Studies of the Walter H. Shorenstein Asia-Pacific Research Center | Includes bibliographical references and index.

Identifiers: LCCN 2015047452 | ISBN 9780804797627 (cloth : alk. paper)

Subjects: LCSH: Transnationalism-Political aspects-Korea-History-2oth century. | Korean diaspora-Political aspects-History-2oth century. | Korea-Emigration and immigration-History—2oth century. | JapanEmigration and immigration-History-2oth century. | China-Emigration and immigration-History—2oth century. | Koreans-Japan-History2oth century. | Koreans_China_History—2oth century.

Classification: LCC JV8757 .K5454 2016 | DDC 323.6089/957009045-dc23

LC record available at http://lccn.loc.gov/2015047452

ISBN 9780804799614 (electronic)

Typeset by Thompson Type in II/I 4 Garamond 
To Hun-Seok Kim 
